\title{
Comparison of Efficacy of Synthetic Pesticides with Botanical Extracts under Field Condition on Cabbage White Butterfly (Pieris brassicae)
}

\author{
Aneela Kanwal1, Mehboob Ahmad2², Isma Khurshid1, Muhammad Pervaiz Khan², Shitab Khan², \\ Imran Ullah'2, Farkhanda Khan², Muhammad Shahid', Shoaibullah Bashir², Mah Rukh4
}

${ }^{1}$ Hazara agricultural research station, Abbottabad, Pakistan

${ }^{2}$ Agricultural Research Institute, D. I. Khan, Pakistan

${ }^{3}$ Agricultural Research Station, Chitral, Pakistan

${ }^{4}$ Baacha Khan University, Charsadda, Pakistan

Email: *mehboobalhazarwi@gmail.com

How to cite this paper: Kanwal, A., Ahmad, M., Khurshid, I., Khan, M.P., Khan, S., Ullah, I., Khan, F., Shahid, M., Bashir, S. and Rukh, M. (2021) Comparison of Efficacy of Synthetic Pesticides with Botanical Extracts under Field Condition on Cabbage White Butterfly (Pieris brassicae). Advances in Entomology, 9, 44-48.

https://doi.org/10.4236/ae.2021.91004

Received: November 18, 2020

Accepted: January 10, 2021

Published: January 13, 2021

Copyright $\odot 2021$ by author(s) and Scientific Research Publishing Inc. This work is licensed under the Creative Commons Attribution International License (CC BY 4.0)

http://creativecommons.org/licenses/by/4.0/

\begin{abstract}
Cabbage white butterfly (Pieris brassicae) is one of the important insect pests of cabbage crop which causes remarkable quantitative or qualitative crop losses. The research was conducted at Hazara Agricultural research station, Abbottabad (Pakistan) to study the effect of different new chemical insecticides, botanical oil and neem seed oil (Azadirachta indica A. Juss.) on the population density of $P$. brassicae. The study showed that neem oil had a significant effect on population of $P$. brassicae in comparison to control treatment. So, neem oil alone or in combination with insecticides can be used for control of $P$. brassicae in vegetable crops for a safer food supply.
\end{abstract}

\section{Keywords}

Botanical Extracts, Efficacy, Cabbage, White Butterfly

\section{Introduction}

Cabbage is one of the most nutritious leafy vegetables and is an excellent source of vitamin $\mathrm{C}$ and vitamin $\mathrm{K}$. A $100 \mathrm{~g}$ edible portion of cabbage contains $1.8 \mathrm{~g}$ protein, $0.1 \mathrm{~g}$ fat, $4.6 \mathrm{~g}$ carbohydrate, $0.6 \mathrm{~g}$ mineral, $29 \mathrm{mg} \mathrm{Ca}, 0.8 \mathrm{mg}$ Fe and 14.1 mg sodium [1] [2]. The production of cabbage was recorded to be 4210 tons in year 2017-2018 in Khyber Pakhtunkhwa (minfir).

The cabbage white butterfly (Pieris brassicae) is an important pest of cauliflower and cabbage in our region [3] as well as world [4]. 74 to $80 \mathrm{~cm}^{2}$ leaf area is 
consumed by the single larvae [5]. 40 percent yield loss was recorded annually in cruciferous vegetables due to this pest [6]. As a result of feeding, the plants either fail to form compact cabbage heads or produce deformed heads [7].

Keeping in view the problems caused by synthetic pesticides and their residues, need is being felt for effective biodegradable pesticides with greater selectivity. Alternative strategies have included the search for new types of pesticides which are often effective against a limited number of specific target species, are biodegradable into nontoxic products and are suitable for use in integrated pest management programs. This criterion is met by the natural plant products derived from plants and has enormous capability to replace the modern agrochemical research. When extracted from plants, these chemicals are referred to as botanicals. The use of botanical pesticides has proved to be one of the prime means to protect crops and their products and the environment from pesticide pollution. Botanicals extract has ability to degrade more rapidly than most chemical pesticides, and is, therefore, considered relatively environment friendly and less likely to kill beneficial pests than synthetic pesticides with longer environmental retention. Most of the botanical pesticides generally degrade within a few days and sometimes within a few hours [8].

Insect repellent and anti-feedant properties have been found in plants such as neem, Azadirachta indica A. Juss, chinaberry, Melia azedarach L., and Warburgia spp. [9]. Botanical insecticides affect only target insects and do not destroy beneficial natural enemies and provide residue-free food and safe environment. Therefore present research has been proposed on use of botanical insecticides as an integrated insect management program which can greatly reduce the use of synthetic pesticide.

\section{Materials and Methods}

The experiment was conducted at Hazara Agriculture Research Station Abbottabad during March-July 2019 and Cabbage seed Variety green light was sown in January and nursery was transplanted on $20^{\text {th }}$ march in the field in randomized complete block design with 3 replications. Each treatment was replicated three times in a subplot size of $3 \times 2 \mathrm{~m}$. Row to row distance was kept $75 \mathrm{~cm}$, while plant to plant distance was $45 \mathrm{~cm}$. There were 4 rows in each plot and each row had 10 plants.

Two insecticidal formulations including control were tested details of which are given in Table 1. Fertilizer, irrigation and all other agronomic practices were carried out in the experimental field when needed. All inputs for example fertilizer application, irrigation, hoeing and other agronomic practices remained same for all cultivars. Observation on population dynamics of insect pests started as soon as their infestation was noticed. Population density was determined on randomly selected plants at weekly interval.

Observations on the $P$. brassicae population from the selected plants were recorded before spray and after 1, 3, 7 days of spray. The population density of the insect was recorded on three randomly selected plants on the basis of 
Table 1. Details of products used in the experiment.

\begin{tabular}{cccc}
\hline treatment & Trade name & Active ingredient & Recommended dose \\
\hline T1 (synthetic pesticide) & Nova Star & Bifinthrine and abamectine & $2.5 \mathrm{ml} /$ litre of water \\
T3 (synthetic pesticide) & Range star & Lambda cahaloyhrine & $2.5 \mathrm{ml} /$ litre of water \\
T2 (botanical oil) & $\begin{array}{c}\text { Neem oil } \\
\text { Purchase from } \\
\text { local market }\end{array}$ & $2 \mathrm{ml} /$ litre of water \\
\hline
\end{tabular}

number of larvae per plant. All the open leaves and heads of the selected plants were observed thoroughly and the number of larvae found were recorded. Data obtained were analysed statistically and the efficacy of the insecticides and botanical oils were worked out.

\section{Results and Discussion}

\section{1) Seasonal Incidence of $P$. brassicae larvae on cabbage}

It was observed that the larvae first appeared on cabbage in the $3^{\text {rd }}$ week of April, and the population peaked during the $3^{\text {rd }}$ week of May 2019, and remained active up to June. In the present investigation, the number of larvae per plant ranged from $0.66-7.53$ (Table 2). It was found that the $3^{\text {rd }}$ and $4^{\text {th }}$ week after transplantation is sensitive to attack of cabbage butterfly so suitable control measures should be done on this stage.

2) Population dynamics of the Cabbage butterfly on green light variety under different treatments

Population dynamics of the Cabbage butterfly on green light variety under different treatments were recorded.

Efficacy of the insecticides revealed that all the treatments at 1,3,7 day after spray were superior to control (Table 2). There was no significant difference between the treatments one day before spray.

The observations recorded on 1st day after spray revealed that all the treatments proved significantly superior over control. Neem seed oil T2 was found to be most effective by ( 1.5 larvae/plant), followed by nova star i.e. bifenthrine (2.83 larvae/plant) where as T3 was found to be least effective (Table 2).

After 3 days of application all the treatments proved significantly superior over control. Neem oil (2.50 larvae/plant) was found to be most effective treatment while T3 was found to be least effective having 3.667 larvae per plant.

$7^{\text {th }}$ day after spray revealed that all the treatments proved significantly superior over control. While neem oil ( 0.6 larvae/plant) was found to be the most effective treatment in reducing the larval population followed by range star and nova star showing 2 and 1.07 larvae per plant.

The relative efficacy of insecticides against the cabbage white butterfly $(P$. brassicae) showed that Neem oil had higher efficacy against $P$. brassicae in reducing pest population. Mean population of $P$. brassicae after two sprays revealed that Neem oil was effective and superior. The bifenthrine was found to be ineffective. 
Table 2. Mean number of larvae under different treatments.

\begin{tabular}{cccccc}
\hline Treatments & $\begin{array}{c}\text { Pre } \\
\text { spray data }\end{array}$ & $\begin{array}{c}1 \text { day } \\
\text { after spray }\end{array}$ & $\begin{array}{c}3^{\text {rd }} \text { day } \\
\text { after spray }\end{array}$ & $\begin{array}{c}7^{\text {th }} \text { day } \\
\text { after spray }\end{array}$ & Means \\
\hline T1 Novastar (Bifinthrine + Abamectin) & 3.5 & $2.83 \mathrm{de}$ & $3.167 \mathrm{~d}$ & $2 \mathrm{e}$ & $2.66 \mathrm{~B}$ \\
T2 Neem oil & 3.6 & $1.5 \mathrm{e}$ & $2.50 \mathrm{de}$ & $0.667 \mathrm{f}$ & $1.55 \mathrm{~A}$ \\
T3 Range star (Lamba cyhalothrin) & 3.5 & $3.1667 \mathrm{~d}$ & $3.667 \mathrm{~d}$ & $1.667 \mathrm{e}$ & $2.7 \mathrm{~B}$ \\
T4 (control) & 3.7 & $4.1667 \mathrm{c}$ & $5.83 \mathrm{~b}$ & $7.500 \mathrm{a}$ & $5.833 \mathrm{C}$ \\
LSD value & N.S & $3.700 \mathrm{~A}$ & $2.958 \mathrm{~B}$ & $2.916 \mathrm{~B}$ & \\
\hline
\end{tabular}

Table 3. Yield (kg/plot) under different treatments.

\begin{tabular}{ccc}
\hline S. No & Techniques & Yield (kg/plot) \\
\hline 1 & (T1) Nova star. & $26.5 \mathrm{~B}$ \\
2 & (T2) Neem oil & $42 \mathrm{~A}$ \\
3 & (T3) Range star. & $27 \mathrm{~B}$ \\
4 & $(\mathrm{~T} 4)$ control & $19.5 \mathrm{C}$ \\
\hline
\end{tabular}

\section{3) Yield}

The highest yield ( $42 \mathrm{~kg} / \mathrm{plot})$ was noted in T2 and the lowest yield was noted in T4 $(19.5 \mathrm{~kg} / \mathrm{plot})$ as presented in Table 3.

Our results matched with the findings of [10] who observed the repellent effect of neem (Azadirachta indica) against $2^{\text {nd }}$ and $3^{\text {rd }}$ instar larvae of Pieri sbrassicae on cabbages. All concentrations of seed kernel suspension and oil emulsion and $2 \%$ leaf water extract had a significant anti-feedant effect, reducing the mean leaf area consumed by $40 \%-50 \%$.

[11] conducted field trials in Himachal Pradesh and evaluated 8 different pyrithriods insecticides in which cypermethrin, decamethrin and fenvalerate gave complete protection to Brassica crop against Pieris brassicae. His study showed same result as our work explained that lambda cahylothrine (pyrithriods) shows effectiveness to control cabbage butterfly larvae.

[12] studied the effects of Neem EC (1\% azadirachtin) on the cabbage white butterfly which is major pest of cruciferous plants and found that neem extract also induced high mortality by causing lethal failures of larval-larval and larval-pupalecdysis, which were typical for insecticides possessing morphogenetic activity commonly referred to as IGR activity. His findings matches to finding of our experiment and revealed that Neem EC had toxic and antifeedant/deterrent effects but also acted as a growth regulator for $P$. brassicae larvae.

\section{Conclusion}

Useful insecticidal and repellent of neem oil extracts can be used to suppress the cabbage white butterfly caterpillars in food crops. In addition, insecticide-botanical combinations can provide cost-effective solutions for crop problems and can be used as an important part of integrated pest management strategies. However, 
achieving more acute interactions, the synergistic mechanism between insecticides and the botanicals should be the focus in future research.

\section{Conflicts of Interest}

The authors declare no conflicts of interest regarding the publication of this paper.

\section{References}

[1] Ojetayo, et al. (2011) Effect of Fertilizer Types on Nutritional Quality of Two Cabbage Varieties before and after Storage. Journal of Applied Biosciences, 48, 3322-3330.

[2] Balliu, A. (2014) Handbook of Vegetables: Cabbage. Agricultural University of Tirana, Tirana, 79 .

[3] Shankar, U., Kumar, D., Singh, S.K. and Gupta, S. (2016) Pest Complex of Cole Crops and Their Management. Technical Bulletin No. 1, SKUAST-Jammu, 14.

[4] Hasan, W., Gupta, A.K. and Singh, C.P. (2008) Biology of Cabbage Butterfly, Pierisbrassicae (L.) (Lepidoptera: Pieridae) on Cabbage and Indian Mustard. Journal of Oilseeds Research, 25, 104-105.

[5] Younas, M., Naeem, M., Raqib, A. and Masud, S. (2004) Population Dynamics of Cabbage Butterfly (Pierisbrassicae) and Cabbage Aphids (Brevicorynebrassicae) on Five Cultivars of Cauliflower at Peshawar. Asian Journal of Plant Sciences, 3, 391-393. https://doi.org/10.3923/ajps.2004.391.393

[6] Hasan, F. and Ansari, M.S. (2010) Effect of Different Cole Crops on the Biological Parameters of Pierisbrassicae (L.) (Lepidoptera: Pieridae) under Laboratory Conditions. Journal of Crop Science and Biotechnology, 13, 195-202. https://doi.org/10.1007/s12892-010-0025-2

[7] Uddin, M.N., Hoque, M.M., Hossain, S.M.M., Alam, S.N., Mollik, A.K.M.S.R., Khorsheduzzaman, A.K.M., Alam, S., Rahman, M.M., Karim, A.N.M.R., Rajotte, E.G. and Luther, G.C. (2007) IPM Approach for Controlling Two Lepidopteran Pests of Cabbage in Bangladesh. Bangladesh Journal of Entomology, 17, 19-29.

[8] Guleria, S. and Tiku, A.K. (2009) Botanicals in Pest Management: Current Status and Future Perspectives. In: Peshin, R. and Dhawan, A.K., Eds., Integrated Pest Management: Innovation-Development Process, Springer, Berlin, 317-329. https://doi.org/10.1007/978-1-4020-8992-3_12

[9] Saxena, R. (1987) Antifeedants in Tropical Pest Management. International Journal of Tropical Insect Science, 8, 731-736. https://doi.org/10.1017/S1742758400022840

[10] Singh, K., Sharma, P.L. and Singh, K. (1987) Evaluation of Antifeedant and Repellent Qualities of Various Neem (Azadirachtaindica) Formulations against Pieris brassicae L. Research and Development Reporter, 4, 76-78.

[11] Thakur, S.S. and Parmar, S. (2000) Field Evaluation of Insecticides against Pieris brassicae Linn. Infesting Cabbage Seed Crop. Insect Environment, 6, 139-140.

[12] Grisakova, M., Metspalu, L., Jogar, K., Hiiesaar, K., Kuusik, A. and Poldma, P. (2006) Effect of Biopesticide Neem EC on the Large White Butterfly, Pieris brassicae (L.) (Lepidoptera: Pieridae). Agronomy Research, 4, 181-186. 